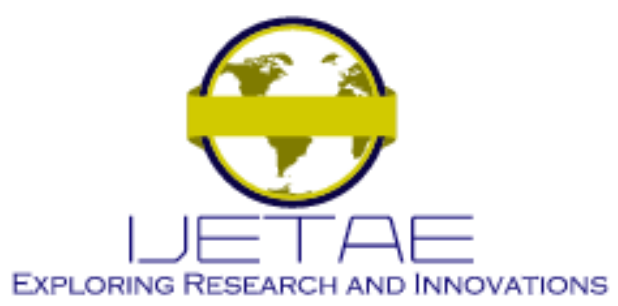

International Journal of Emerging Technology and Advanced Engineering

Website: www.ijetae.com (E-ISSN 2250-2459, Scopus Indexed, ISO 9001:2008 Certified Journal, Volume 11, Issue 09, September 2021)

Manuscript Received: 02 August 2021, Received in Revised form: 12 September 2021, Accepted: 16 September 2021 DOI: 10.46338/ijetae0921_06

\title{
Mobile Application for the Monitoring and Control of Electrical Energy Consumption through a Meter Made with Arduino
}

\author{
Keyla Nalvarte-Dionisio ${ }^{1}$, Carlos Diaz-Nuñez ${ }^{2}$, Alexi Delgado ${ }^{3}$, Enrique Lee Huamaní ${ }^{4}$ \\ ${ }^{1,2}$ Systems engineer program, Universidad de Ciencias y Humanidades, Lima-Perú \\ ${ }^{3}$ Mining Engineering Section, Pontificia Universidad Católica del Perú, Lima-Perú \\ ${ }^{4}$ Image Processing Research Laboratory, Universidad de Ciencias y Humanidades, Lima Perú
}

\begin{abstract}
This year, citizens were complaining that the power companies were overcharging their bills because of the pandemic, but investigations in previous years also showed claims in Peru and internationally. In this work, the Scrum Methodology was used for the development of the mobile application and the Balsamiq tool was used for the design of the prototype. In addition, the Arduino tool was used for the electricity consumption meter. As for the case study, we developed the prototypes of the application with its functions and the methodology of how it is elaborated, at the same time we described the way in which the meter will be implemented with Arduino. The results obtained from the research are that people can compare the consumption of the bill issued by the electricity company and the consumption shown by the Arduino meter, in addition to the union of the mobile application with the meter will allow them to consult the consumption and also issue reports having a better control of electricity. This work can be implemented not only in the cities, but also in remote places where traditional meters have not been implemented.
\end{abstract}

Keywords - Arduino; Mobile applications; Power consumption; Scrum methodology.

\section{INTRODUCTION}

With large-scale electrical network installations, an important requirement is an electrical energy meter to account for its consumption [1]. At present, in order to calculate electrical energy consumption, meters are used whose standard unit of measurement is the kilowatt-hour, and they are invoiced month by month by employees who read them personally [2]. Consequently, a miscalculation can generate claims for the use of electricity, whether due to excessive or misplaced charges. These claims are not only presented in a particular site, but we can observe it in different parts of the world. As happened in Spain in 2017, where more than half a million claims were registered [3], or in the city of Lima, which, due to the pandemic, registered more than 70,000 claims in June 2020 alone [4].
For these reasons, it is important to develop a meter to help verify the readings that come from the electricity companies.

The methodology to be implemented for the development of the mobile application will be Scrum, since being an agile type of development, changes can be accepted at any stage of development and not only that, but also predict inevitable changes in the future [5]. In comparison with a traditional methodology that, within the phases that compose it, the end user only intervenes in the analysis phase and in the delivery of the product [6]; leaving for the end substantial changes that may arise during its development. On the other hand, the electric energy consumption meter will be implemented with the Arduino tool, since it has a great capacity of implementation options and is of low cost [7]. Similarly, the Balsamiq tool will be used to develop the prototypes to be implemented.

With regard to the case study, it is shown how the Scrum methodology is going to be implemented for the development of the mobile application, using the planning phases of the sprint, development stage, review and feedback of the sprint [8]; where the prototypes that the application will have will be exposed. In addition, the components that the meter will have with the Arduino tool will be described.

The objective of this article is to develop a prototype of a mobile application for monitoring electrical energy consumption, using a meter made with Arduino's tool, in order to make a comparison of our electrical consumption with the reading that comes in the bills of the electrical companies.

This article is structured as follows: in section II the literature review, in section III the methodology to be implemented, in section IV the Case Study, in section V the Results and Discussions obtained and in section VI the Conclusions reached. 


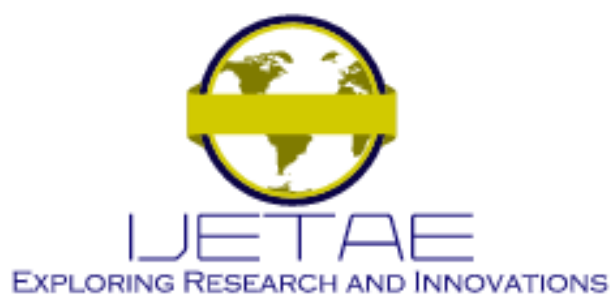

International Journal of Emerging Technology and Advanced Engineering

Website: www.ijetae.com (E-ISSN 2250-2459, Scopus Indexed, ISO 9001:2008 Certified Journal, Volume 11, Issue 09, September 2021)

\section{LITERATURE REVIEW}

According to the author [9] The electromechanical energy meter consists of a disk that has a rotational speed directly proportional to the current consumed. This content has a magnetic sheet core in which are displayed two intensity coils and the other in derivation on the conductors called voltage coil which is very important for the calculation for the implementation of an electric meter for a house whose purpose is the prevention of consumption and energy saving. In addition, the Arduino System will be in charge of processing the preventive data of the metering elements, in addition it will be able to send the readings of the consumed energy.

According to the author [10] the system is going to be composed of the current transducer and its rectifier circuit, the main Arduino and the base station equipment. The current was measured from two wires carrying the currents were measured from the two wires carrying the current on the main power panel, sampled by the Arduino board, and then sent as a UDP packet over the WIFI network to the base station equipment. The base station software analyzes the data packet, where it acquires the analog data and converts it into digital data.

According to the author [11], the current governing body for WI-FI technology is the IEEE (Institute of Electrical and Electronics Engineers), under the IEEE 802.11b standard. This standard describes the technical details for establishing wireless communications at a maximum speed of $11 \mathrm{Mbps}$. Therefore, the original WI-FI standard only allows data to be transmitted at a speed of $11 \mathrm{Mbps}$. Also, in order to measure the electric current of a residential installation, not only a transformer that can measure the current must be used, but it is essential to ratify the waveform and attenuate the values that may be appropriate with the analog pins of the Arduino board.

The author [12] says that one of the most important problems is in the billing area as the deficiency in the reading of the energy consumption record of the users, since it is identified as one of the causes of the elevated problem of the error of the technical staff that takes the reading at the time of reading the data of the energy meter that was located in each house or also one of the failures is of the staff that passes the readings to the computer.
That is why they developed the proposal of a solution of an application for the registration of energy consumption reading.

\section{Methodology}

In the development of the application will have to implement the methodology of scrum and technological tools that include hardware and software, such as Arduino, sensors, Android Studio, etc.., Which will allow us to develop a mobile application that manages to monitor the use of electricity consumption, through a meter made with Arduino.

\section{A. Scrum methodology}

Scrum focuses on project management in situations where long-term planning is difficult, with "empirical process" control mechanisms, where feedback loops establish the central element. The software is developed by a self-organizing team in increments called sprint, starting with planning and ending with a comment [8]. Then, by using the Scrum methodology in our project, it will make the application develop in an agile way, focusing on what is most important and making a better monitoring that will be done in order to indicate the time spent in developing the tasks that will be used in each of them.

Planning the Sprint: It is allowed to establish objectives of the product backlog, that is, the list of tasks that will be developed in the project in a certain time

Development stage: When the work of the sprint is being carried out, it should be observed that it does not have last minute changes, because it could affect the objectives proposed in the project.

Sprint Review: It allows to analyse and evaluate the results that were developed in the sprint, because of that, it is determined if it has been done well or should be returned to the planning phase to improve the sprint.

Feedback: In this phase, we are allowed to see the results and can inspect ourselves to implement new plans to execute our next sprint.

As can be seen in Figure 1, the explanation of the stages that will be developed with respect to the research using the scrum methodology is shown [13]. 


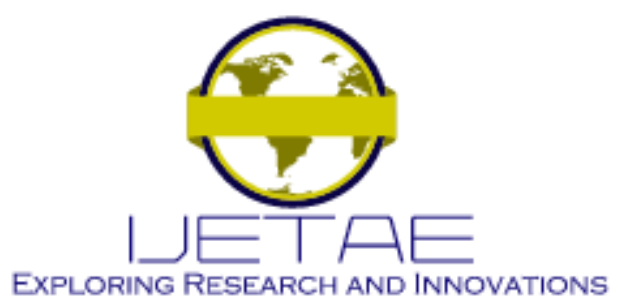

International Journal of Emerging Technology and Advanced Engineering

Website: www.ijetae.com (E-ISSN 2250-2459, Scopus Indexed, ISO 9001:2008 Certified Journal, Volume 11, Issue 09, September 2021)

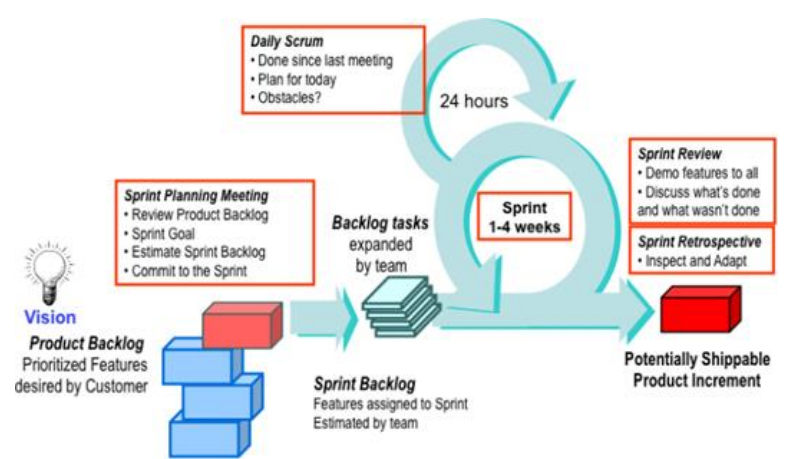

Figure 1: Release Planning in Scrum

\section{B. Prototyping tools.}

Balsamiq is used to develop the prototype of the proposed solution, as it is a fast, low-fidelity user interface tool that reproduces the experience of drawing on a notebook or blackboard [14], allowing the development of a mobile application prototype that will show the consumption of electricity. This helps to have a reference of the application interfaces to be used.

\section{Technological tools for application.}

Hardware: For the development of the meter, the Arduino will be implemented, since it is a tool that allows us an easy connectivity to a network, besides that a protocol like HTTP (Hypertext Transfer Protocol) can be implemented; it has the processing capacity, memory, compilers and ports that allow us to connect them to a device [15]. This sends the data obtained from the sensors to the Web server. In addition, sensors have to be implemented to help measure the flow of energy. The one to be used is the SCT-013 sensor, since it works as a current transformer, allowing the measurement of the amount circulating inside the wiring [16]. Its implementation is of paramount importance for obtaining accurate and real-time energy flow that is used. The ratio or proportion of the current flow is calculated by means of loops.

Development Tools: To develop the project application that shows the interface of the results of the electrical energy consumption proposed in the prototype, the Android Studio integrated development environment (IDE) is used, which is designed to allow developers to create mobile applications that can be exploited to the fullest extent of all the resources that a mobile device can offer [16].
As a programming language to be developed in Android Studio will be Kotlin, as it serves to create Java applications, because Android uses specialized versions of the Java Virtual Machine, being an application open to an instance of that machine [17]. And as a database manager to store each of the information will be used SQLite which is a relational database manager and open source, it is also too light. Another feature is that it saves the entire database in a single file. It is useful for small applications that do not require the additional installation of a database manager, as well as for embedded devices with limited resources, also the database will allow, read, write, delete, and other operations that our program may require [18].

\section{CASE StUdy}

This section describes the Arduino meter and the SCT013 sensor. In addition, it is developed which is the planning of the Sprint of each one of the modules and the estimations of the determined time in which the stage of the development of the mobile application will be carried out.

\section{A. Arduino Meter}

To obtain the flow of electrical energy in real time, the SCT-013 sensor is placed on the electrical cable, so that when it is attached, the amount of current flowing through the cable can be determined. The voltage obtained is received by the Arduino Nano, through an analog-to-digital converter, as shown in Figure 2 [19].

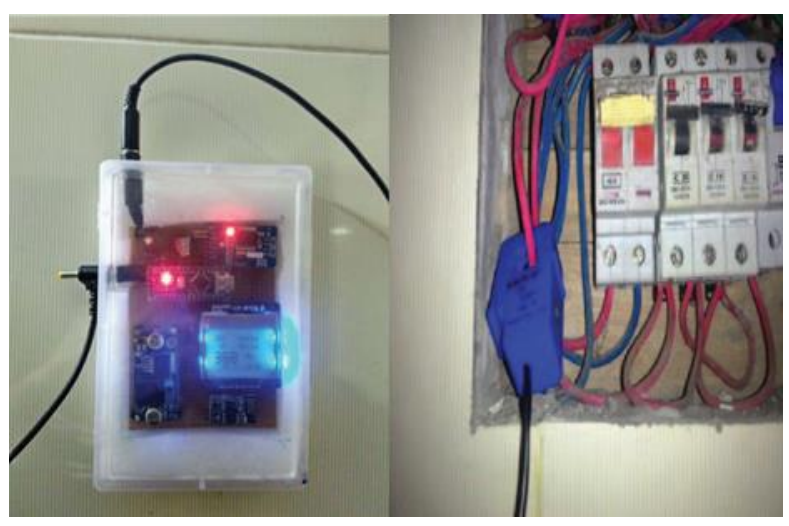

Figure 2: Meter with Arduino and SCT-013 sensor.

To connect the Arduino to the Wifi module, the ESP8266Wifi library will be used. Figure 3 shows the code that allows the connection. 


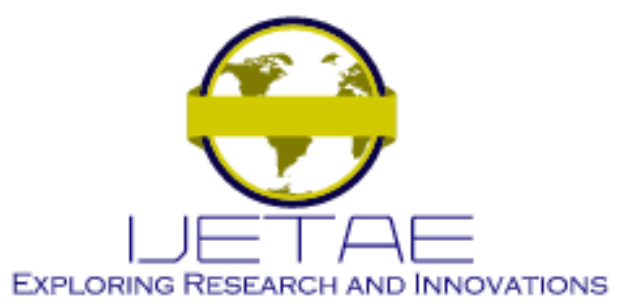

International Journal of Emerging Technology and Advanced Engineering

Website: www.ijetae.com (E-ISSN 2250-2459, Scopus Indexed, ISO 9001:2008 Certified Journal, Volume 11, Issue 09, September 2021)

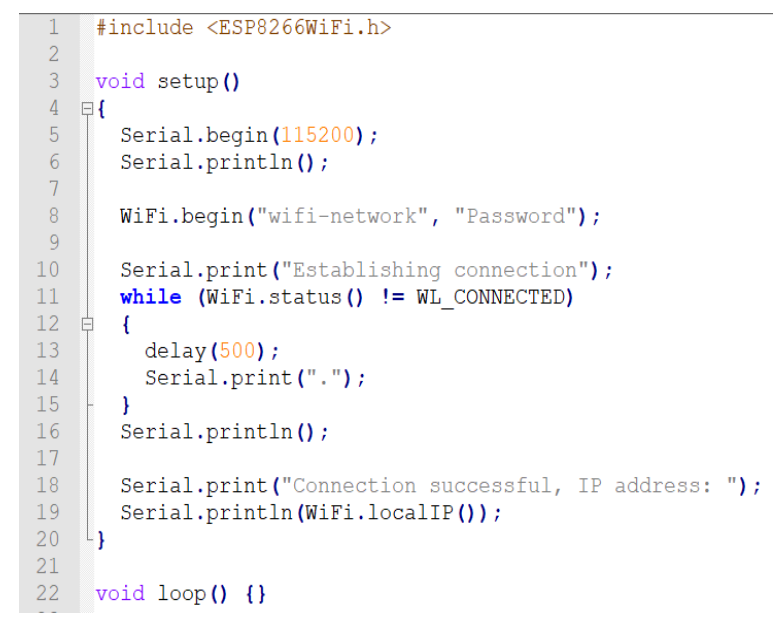

Figure 3: Code.

The sending of data is processed to the server by means of the GET method, using the libraries provided by the Arduino itself, as shown in Figure 4.

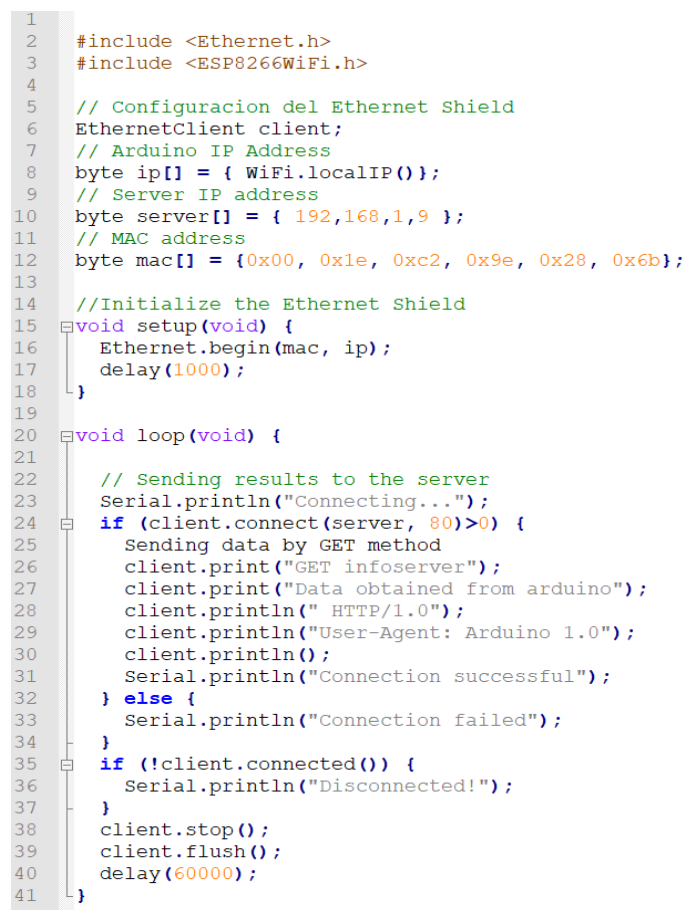

\section{Figure 4: Code.}

Figure 5 shows the entire data flow, which begins from the installation of the SCT-013 in the power cable to the sending of data by Arduino.

\section{IMPORTING DATA TO THE MOBILE APPLICATION}

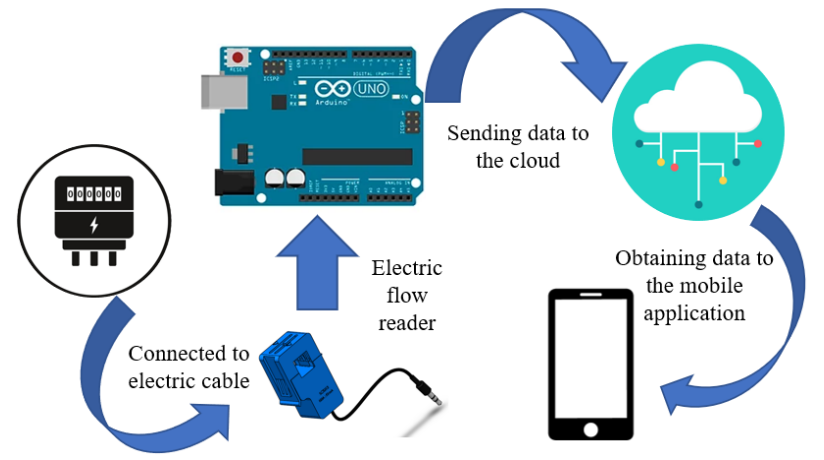

Figure 5: Code.

B. Sprint Planning.

- As a user I want to enter credentials through a Login to access the application.

- As a user I want to register adding my data to have an account and enter the application.

- As a user I want to link to the meter made with Arduino to be able to receive the data of the electrical energy.

- As a user I want to obtain the data of the electrical energy consumption to have a better control of the light.

- As a user I want to get the graphs of the consumption of each month to compare with previous months.

- As a user I want to generate more detailed reports to be displayed later.

C. Development Stage.

Time estimation: In this phase we will show the duration of each of the Sprint as shown in Table 1.

TABLE I

DURATION OF SPRINT

\begin{tabular}{|c|c|}
\hline Module Name & Duration \\
\hline $\begin{array}{c}\text { Mobile application for monitoring } \\
\text { electrical energy consumption }\end{array}$ & 3 months \\
\hline Login Module & 1 week \\
\hline Registry Module & 2 weeks \\
\hline Connection Module & 2 weeks \\
\hline Data Module & 2 weeks \\
\hline Consumption Detail Module & 3 weeks \\
\hline Reports Module & 2 weeks \\
\hline
\end{tabular}




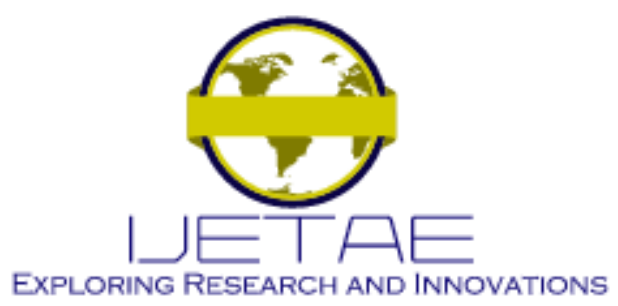

International Journal of Emerging Technology and Advanced Engineering

Website: www.ijetae.com (E-ISSN 2250-2459, Scopus Indexed, ISO 9001:2008 Certified Journal, Volume 11, Issue 09, September 2021)

Scope of the product: It is the estimate of the time it will take for the equipment to have the points of the user history, therefore, all the estimates of the scope of the equipment are shown in Figure 6.

\section{PRODUCT CONSUMPTION TABLE}

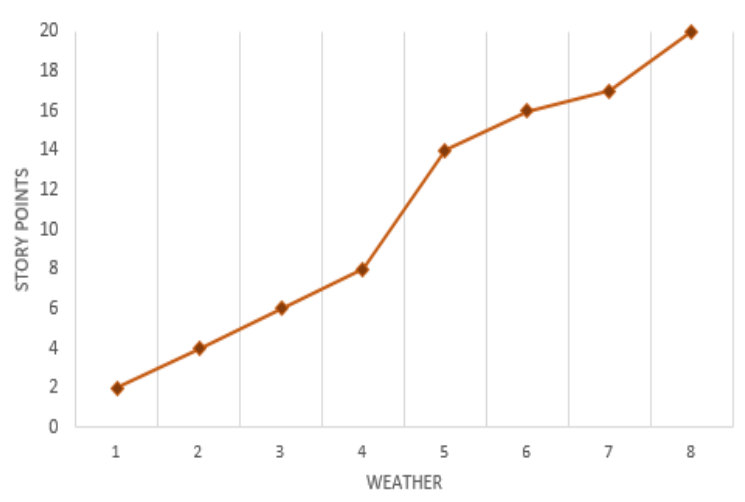

Figure 6: Code.

Mobile Application Prototypes: This stage shows the creation of the design of the mobile application and details the functions that each of the modules will have, as shown in Figure 7, Figure 8, Figure 9, Figure 10, Figure 11, Figure 12 and Figure 13.

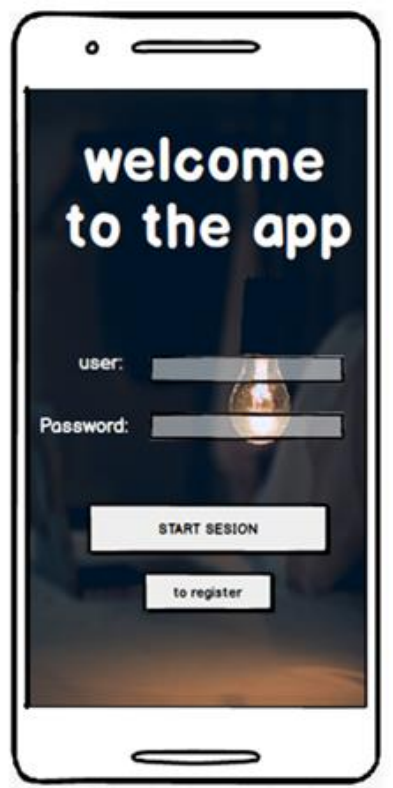

Figure 7: Login Module

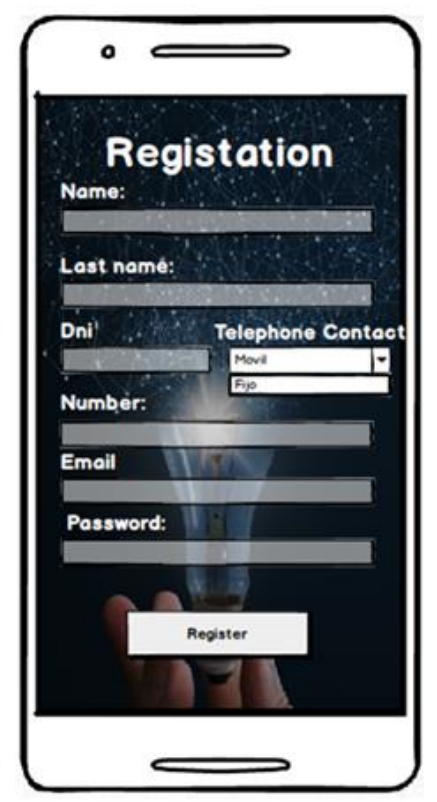

Figure 8: Registration Module

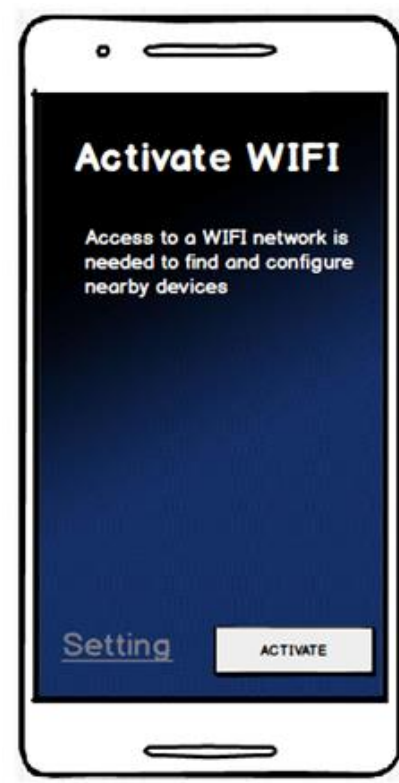

Figure 9: Connection Module

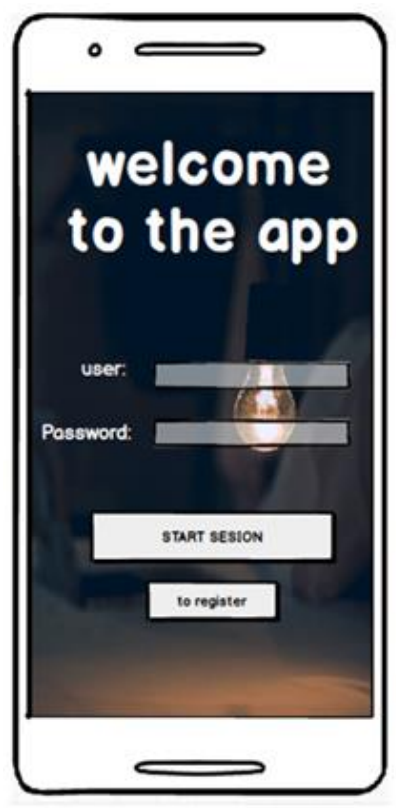

Figure 11: Data Module

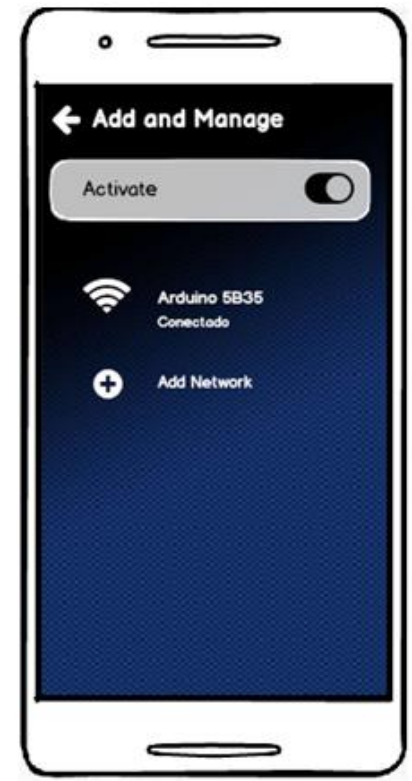

Figure 10: Connection Module

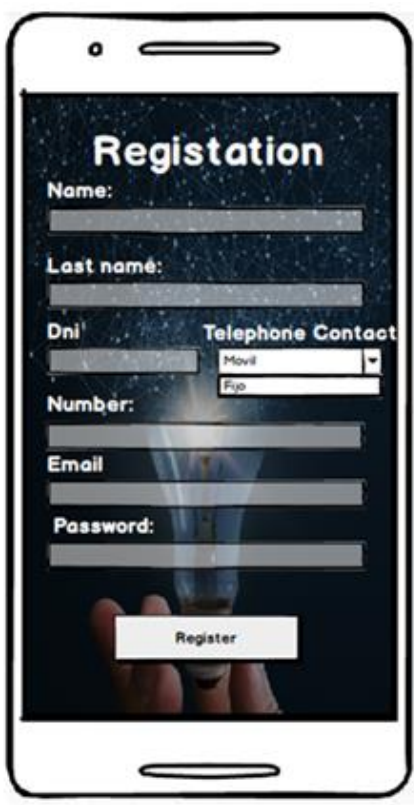

Figure 12: Consumption detail module 


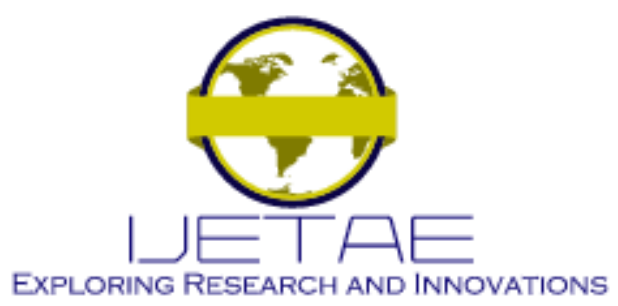

International Journal of Emerging Technology and Advanced Engineering

Website: www.ijetae.com (E-ISSN 2250-2459, Scopus Indexed, ISO 9001:2008 Certified Journal, Volume 11, Issue 09, September 2021)

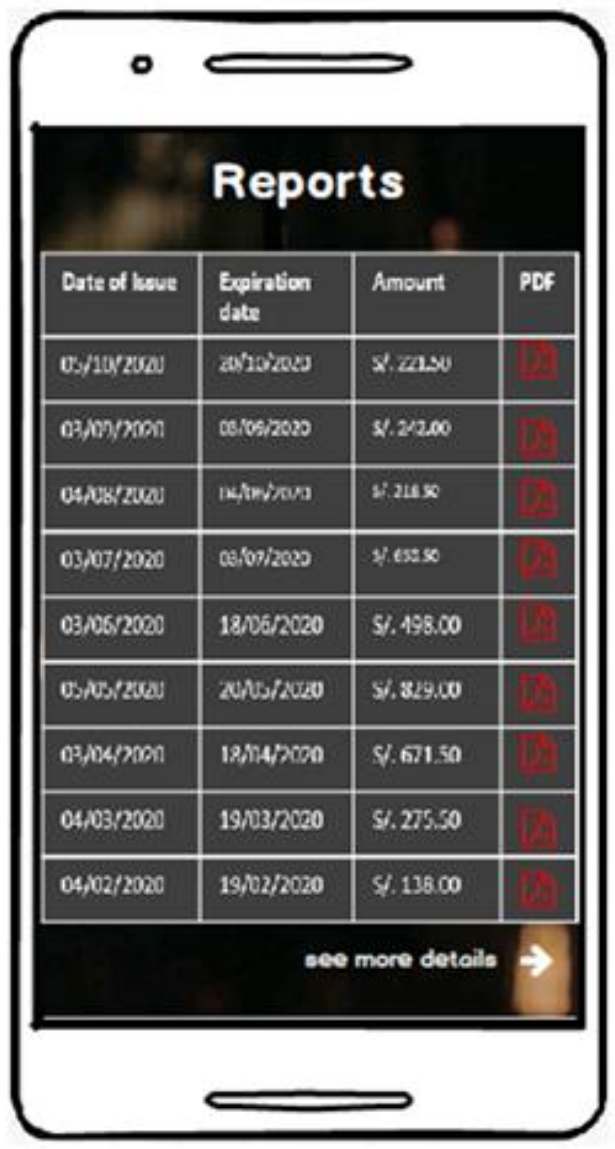

Figure 13: Report module

Increase of the mobile application modules: The following describes each function of the modules and their relationship to each prototype developed.

\section{Increment 1: Login Module.}

In this increment a login is shown, you must register your credentials to be able to enter, as shown in Figure 5.

\section{Increment 2: Registration Module.}

In this module you can register to enter the application, you must enter some data, as shown in Figure 6.

\section{Increment 3: Connection Module.}

This increment allows you to link the mobile device to the Arduino meter as shown in Figure 7 and Figure 8; this way you can get the reading data.

\section{Increment 4: Data Module.}

The Data Module allows you to change some parts of your personal information, such as your password, as shown in Figure 9.

\section{Increment 5: Consumption Details Module.}

In this increase you can view readings of electricity consumption with dates, results of previous months, etc., as exemplified in Figure 10.

\section{Increment 6: Reporting Module.}

This module can print detailed reports on readings for any month, day, or date range; as shown in Figure 13.

\section{Sprint Review.}

When the Sprint is finished, it is reviewed by the team, with a review time of two to three hours. One of the team members evaluates each task developed and determines if any changes are needed. In addition, the development team members explain each process and the solutions they implemented when they had problems while developing the Sprint.

\section{E. Sprint Feedback.}

Team members evaluate each process and technique implemented during the development of the Sprint. For example, the use of the Kotlin programming language, the SQLite database manager or the Balsamiq tool for the development of the prototypes. New ideas or methods can be suggested for the gradual improvement of each Sprint.

\section{RESULTS AND DISCUSSION}

Next, the expected results are shown with respect to the development of the investigation of the article within the case study and the methodology, taking into account the application that was developed and the implementation of the control system, to later carry out the analysis that is compared with other investigations, of which they present similarities or inequality with respect to the development of the methodology chosen for the application, taking into account the phases that intervene in it and in their way of presenting the execution.

\section{A. About the case study.}

Currently, in the city of Lima more than 50,000 complaints have been registered and 80,000 nationally, due to the high increases in electricity rates during the months of June and July of this year [4]. 


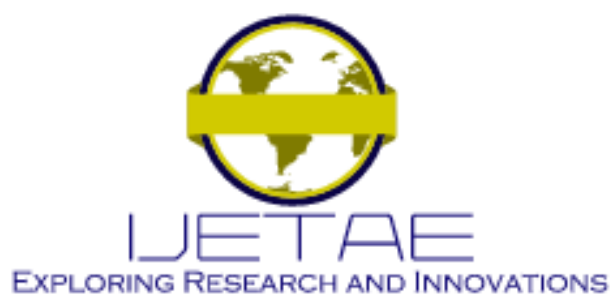

International Journal of Emerging Technology and Advanced Engineering

Website: www.ijetae.com (E-ISSN 2250-2459, Scopus Indexed, ISO 9001:2008 Certified Journal, Volume 11, Issue 09, September 2021)

Similarly, claims for this service are reflected in other countries, such as Spain, which is the sector that presented the most claims during 2017, which reached up to 1.13 million claims by its consumers, half of them for billing, as shown in Figure 14 [3]. Therefore, problems with electricity consumption readings occur every year and are evident in all countries. Likewise, if electricity consumption is not properly controlled, it is more likely that consumer dissatisfaction will continue to occur. For this reason, the implementation of the case study allows users to compare the consumption that comes in the receipts of the electricity companies with the approximate calculation of the Arduino Meter in the mobile application.

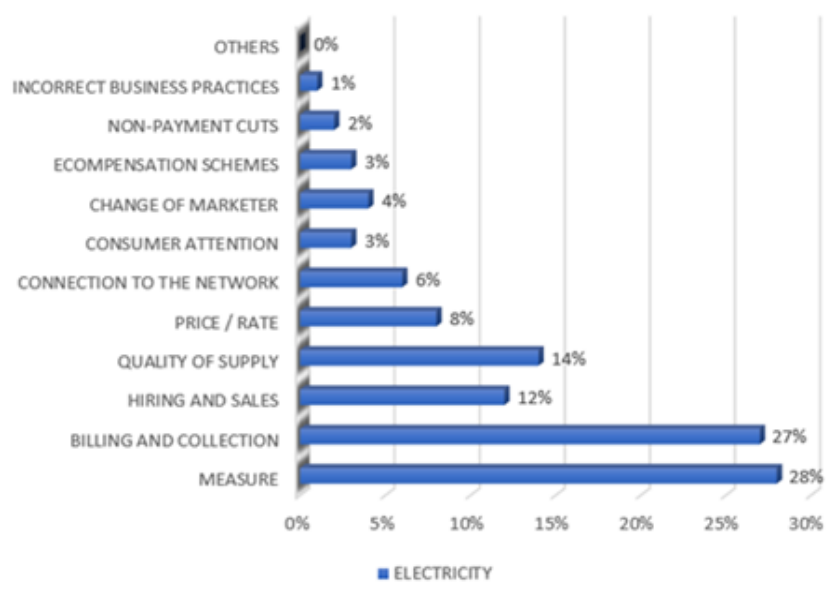

Figure 14: Reasons for claims in the electricity sector. Year 2017.

As a case study, the design of the mobile application has been elaborated in such a way that it is easy to use and does not require training for the end user; so that there is better interaction with all its functionalities. Balsamiq was the tool used to make all the prototypes since, being easy to use, changes can be made faster than other tools.

In an article they elaborate the Energy Meter with Arduino and link it only showing the data obtained with a text message to a cell phone or LCD screen [20].
In contrast to the case study, an interactive application was developed where it not only shows the data obtained with the Arduino meter, but you can register your personal data to be able to issue reports with your own data, a login for the protection of information, statistical tables on electricity consumption, among others.

In another study, an Arduino meter is used to develop a billing system for their electricity consumption, which will help to have a better control of their energy use; showing their information in a GSM module (Global System for Mobile communications) to notify the excessive use [21]. Although this article does not present an automated invoice system, the case study proposes that all the data obtained be stored in a database, in order to later prepare the necessary reports for the user on the use of electrical energy, download a PDF file and view the history of the same reports, as can be seen in Figure 10 and Figure 13.

\section{B. About the Methodology.}

In this project the methodology that was used is the Scrum methodology, which is a simple and useful framework for management that allows the selection of multidimensional teams to have good results [22], in addition the team is committed to a particular objective for an iteration and is given authority and responsibility to decide how best to meet it [23]. Unlike the RUP methodology which is a comprehensive framework that provides practices for the delivery and implementation of software and effective project management, its goal is to ensure the production of high quality software that meets the needs of end users [24]. In conclusion, the scope of the RUP is defined before the beginning of the project and is embodied in the document, so it is reviewed throughout, but there is a strict process that controls the revisions, instead, the scope of the scrum is defined with the list of objectives, i.e., the backlog and is reviewed at the end of each interaction (Sprint).

Difference of methodologies: This section details the differences of using the agile methodology, as opposed to using traditional methodologies as shown in Table 2. 


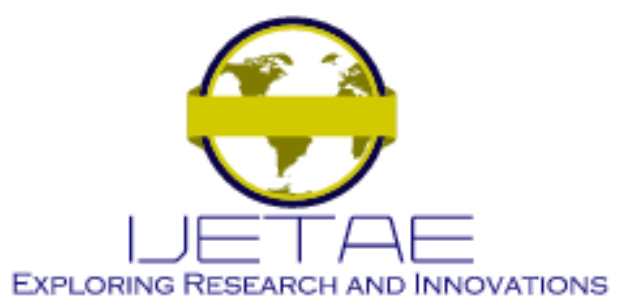

International Journal of Emerging Technology and Advanced Engineering

Website: www.ijetae.com (E-ISSN 2250-2459, Scopus Indexed, ISO 9001:2008 Certified Journal, Volume 11, Issue 09, September 2021)

TABLE II

DifFERENCE Between Traditional Methodology AND AgILE METHODOLOGY.

\begin{tabular}{|l|l|}
\hline $\begin{array}{l}\text { Traditional } \\
\text { Methodologies }\end{array}$ & Agile methodology \\
\hline $\begin{array}{l}\text { Based on norms coming } \\
\text { from standards followed by } \\
\text { the development } \\
\text { environment. }\end{array}$ & $\begin{array}{l}\text { Based on heuristics from } \\
\text { code production practices. }\end{array}$ \\
\hline Some resistance to change. & $\begin{array}{l}\text { Are prepared for changes } \\
\text { during the project. }\end{array}$ \\
\hline Externally imposed. & Imposed by the team \\
\hline $\begin{array}{l}\text { Much more controlled } \\
\text { process, with numerous } \\
\text { Standards. }\end{array}$ & $\begin{array}{l}\text { Less controlled process, } \\
\text { with few principles. }\end{array}$ \\
\hline More Roles. & Few roles. \\
\hline $\begin{array}{l}\text { The client interacts with the } \\
\text { development team through } \\
\text { meetings. }\end{array}$ & $\begin{array}{l}\text { The client is part of the } \\
\text { development team }\end{array}$ \\
\hline
\end{tabular}

\section{CONCLUSIONS AND Future WorK}

In this work we were able to design the prototype of the application using the Balsamiq tool, because it is simple to use and is well known for the design of the interfaces as it aims to help all people who decide to monitor their electricity consumption showing the data and generating reports, also used a meter made with Arduino that contributes to better control.

After the implementation of the scrum methodology for the development of the mobile application made it have a better flexibility and adaptation to the needs, also applying each phase of the methodology was developed optimally, then also has a great risk mitigation if it can occur during the project.

It is recommended in future research work to implement the meter with Arduino not only in urbanized sites, but for distant places that do not have much population and that a traditional meter is not implemented. In addition, add more features such as seeing if other homes are connecting to your meter by performing a power theft.

\section{REFERENCES}

[1] C. Y. Ying, D. Jie, Z. Feng, X. Ji, and Y. H. Xiao, “Application of variable weight fuzzy analytic hierarchy process in evaluation of electric energy meter," Proc. 2017 IEEE 2nd Adv. Inf. Technol. Electron. Autom. Control Conf. IAEAC 2017, pp. 1985-1989, 2017, doi: 10.1109/IAEAC.2017.8054362.

[2] H. K. Patel, T. Mody, and A. Goyal, "Arduino Based Smart Energy Meter using GSM," Proc. - 2019 4th Int. Conf. Internet Things Smart Innov. Usages, IoT-SIU 2019, 2019, doi: 10.1109/IoTSIU.2019.8777490.

[3] CNMC, "Los consumidores presentaron 1,5 millones de reclamaciones contra las compañías de electricidad y gas durante 2017," Madrid, 2018. [Online]. Available: https://www.cnmc.es/en/node/371070.

[4] C. Silva, "Osinergmin: Hay cerca de 80 mil reclamos por recibos de luz y gas natural en el país," La República, Jul. 04, 2020.

[5] B. Mathur and S. M. Satapathy, "An analytical comparison of mobile application development using agile methodologies," Proc. Int. Conf. Trends Electron. Informatics, ICOEI 2019, vol. 2019April, no. Icoei, pp. 1147-1152, 2019, doi: 10.1109/icoei.2019.8862532.

[6] M. Singh, N. Chauhan, and R. Popli, "A Framework for Transitioning of Traditional Software Development Method to Distributed Agile Software Development," IEEE Int. Conf. Issues Challenges Intell. Comput. Tech. ICICT 2019, 2019, doi: 10.1109/ICICT46931.2019.8977654.

[7] T. S. Gunawan, M. H. Anuar, M. Kartiwi, and Z. Janin, "Development of Power Factor Meter using Arduino," 2018 IEEE 5th Int. Conf. Smart Instrumentation, Meas. Appl. ICSIMA 2018, no. November, pp. 1-4, 2019, doi: 10.1109/ICSIMA.2018.8688750.

[8] Y. D. Amaya Balaguera, "Metodologías ágiles en el desarrollo de aplicaciones para dispositivos móviles. Estado actual," Rev. Tecnol., vol. 12, no. 2, 2015, doi: 10.18270/rt.v12i2.1291.

[9] S. I. DIEGO ISRAEL and V. O. DIEGO FERNANDO, Diseño e implementación de un medidor de energía electrónico para vivienda, con orientación a la prevención de consumo y ahorro energético. 2016.

[10] B. Z. JORGE ELIECER, "MONITOR DE ENERGÍA ELÉCTRICA CON INTERFACE INALÁMBRICA PARA SISTEMA MONOFÁSICO,” Rev. Bras. Ergon., vol. 9, no. August, p. 10, 2016, [Online]. Available: https://www.infodesign.org.br/infodesign/article/view/355\%0Ahttp:/ /www.abergo.org.br/revista/index.php/ae/article/view/731\%0Ahttp:// www.abergo.org.br/revista/index.php/ae/article/view/269\%0Ahttp:// www.abergo.org.br/revista/index.php/ae/article/view/106.

[11] B. D. Núñez Rocha, E. I. Romero García, and G. Á. Ramírez Salazar, "Monitoreo del consumo de la energía eléctrica por medio de una aplicación android," p. 180, 2016, [Online]. Available: https://tesis.ipn.mx/bitstream/handle/123456789/22263/MONITORE O DEL CONSUMO DE LA ENERGÍA ELÉCTRICA POR MEDIO DE UNA APLICACIÓN ANDROID.pdf?sequence=1\&isAllowed=y. 


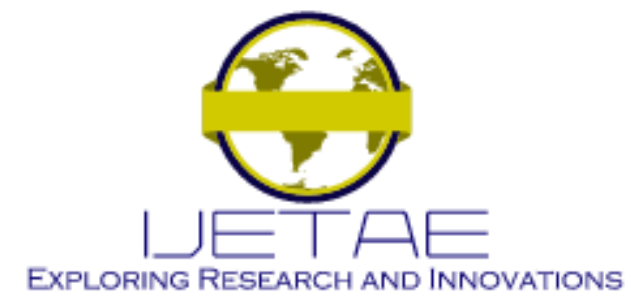

International Journal of Emerging Technology and Advanced Engineering

Website: www.ijetae.com (E-ISSN 2250-2459, Scopus Indexed, ISO 9001:2008 Certified Journal, Volume 11, Issue 09, September 2021)

[12] G. C. YOLANDA, Implementación de una aplicación para el registro de lectura de consumo de energía eléctrica mediante la captura de imágenes con un dispositivo móvil para el área de facturación de la empresa electro oriente s.a - jaén,” pp. 1-215, 2020.

[13] M. Sliger, "Agile project management with Scrum," 2011. https://www.pmi.org/learning/library/agile-project-managementscrum-6269.

[14] "Balsamiq," 2020. https://balsamiq.com/wireframes/.

[15] W. I. M. Yuit, D. D. C. Barrón, and H. J. C. Cardeña, "Desarrollo de competencias de UXD utilizando paper prototyping y balsamiq en estudiantes de Ingeniería en Sistemas Computacionales," vol. 1, no. 383, pp. 1-8, 2016, [Online]. Available: http://reted.remitee.org/index.php/reted/article/view/23.

[16] F. E. Rivas Cárdenas, "Diseño Y Construcción De Una Aplicación Móvil Para La Medición Y Monitoreo De Señales De Corriente Eléctrica Utilizando Arduino.," p. 28, 2017.

[17] C. E. C. Hernández, “Aplicación móvil con Android para el seguimiento de toma de medicamentos usando Kotlin.," pp. 1-125, 2019.

[18] J. R. H. GARCÍA, “ Base de datos con aplicaciones móviles android ." 2016.

[19] S. Thakare, A. Shriyan, V. Thale, P. Yasarp, and K. Unni, "Implementation of an energy monitoring and control device based on IoT," 2016 IEEE Annu. India Conf. INDICON 2016, 2017, doi: 10.1109/INDICON.2016.7839066.
[20] S. Chaudhari, P. Rathod, A. Shaikh, D. Vora, and J. Ahir, "Smart energy meter using Arduino and GSM," Proc. - Int. Conf. Trends Electron. Informatics, ICEI 2017, vol. 2018-Janua, pp. 598-601, 2018, doi: 10.1109/ICOEI.2017.8300772.

[21] M. Abrarul Alam and M. Zeyad, "Smart Cities and Buildings: GSM Based Smart Electric Energy Meter Billing System," 2019 IEEE Int. Conf. Power, Electr. Electron. Ind. Appl. PEEIACON 2019, pp. 1-4, 2019, doi: 10.1109/PEEIACON48840.2019.9071923.

[22] M. Usman, T. R. Soomro, and M. N. Brohi, "Embedding Project Management Into XP, SCRUM and RUP,” Eur. Sci. J., vol. 10, no. 15, pp. 293-307, 2014.

[23] L. Williams, "A Survey of Agile Development Methodologies," Univercsty West Engl., pp. 209-227, 2007, [Online]. Available: http://www.cems.uwe.ac.uk/ pchatter/2011/isd_hk/AgileMethods.pd f.

[24] P. Y. Reyes-Delgado, M. Mora, H. A. Duran-Limon, L. C. Rodríguez-Martínez, R. V. O’Connor, and R. Mendoza-Gonzalez, "The strengths and weaknesses of software architecture design in the RUP, MSF, MBASE and RUP-SOA methodologies: A conceptual review," Comput. Stand. Interfaces, vol. 47, pp. 24-41, 2016, doi: 10.1016/j.csi.2016.02.005. 